\title{
EFFECT OF WATER DEPTH ON GROWTH PERFORMANCE AND SURVIVAL RATE OF MIXED SEX NILE TILAPIA FINGERLINGS AND ADULTS
}

\author{
M.A.M. Ali, A.M.I. El-Feky*, H. M. Khouraiba and M.S. El-Sherif \\ Department of Animal Production and Fish Resources, Faculty of Agriculture, Suez Canal \\ University, Ismailia 41522, Egypt \\ *Corresponding author Email: (amal_elfeky@yahoo.com)
}

\section{SUMMARY}

Nile tilapia (O. niloticus) fingerlings and adult averaging (18 and $100 \mathrm{~g}$ in weight) respectively, were reared under 3 different depths $(75,125$ and $175 \mathrm{~cm})$ for 90 days to study the effect of water depth on the growth and the survival of overwintered fishes using twelve standing cages. Fish were fed on a commercial diet containing $26.58 \%$ protein. The dissolved oxygen, temperature, $p H$, UIA-N and transparency of water and mortality were recorded for each cage every 15 days during the experimental period. Also, at the end of the experimental period, the fish were harvested, counted and the growth measurements (weight and total length) were determined. The statistical analyses indicated that there were significant differences $(\leq 0.05)$ in all parameters between all depths. Results showed that the final average total length, weight gain, condition factor and survival rate being the best at depth of $175 \mathrm{~cm}$ in both two sizes of tilapia during the cold season in Egypt.

Keywords: Nile tilapia, water depth, performance, survival rate

\section{INTRODUCTION}

Enhancement of tolerance to low temperature of Nile tilapia, Oreochromis niloticus, is important to prolong its growth period, reduce mortality for overwintering and decrease costs (Sifa et al., 2002). In temperate and some sub-tropical regions, their culture is highly affected by sensitivity to low water temperatures leading to poor growth and mass mortality during over-wintering (Charo-Karisa et al., 2005). Fish naturally tend to select the habitat that is most suitable for their physiological requirements. This behavior is known as 'habitat selection' or 'enviroregulation'. Therefore, fish move into deeper water when surface water temperature decreases or increases beyond their preferred range. So, fish ponds should be deep enough to meet temperature demands and other habitat requirements of cultured fish, especially in arid areas where diurnal and seasonal fluctuations in water temperature occur. (Neill and Bryan, 1991). Depth as a factor in pond ecosystem management has been given little experimental attention, despite its theoretical importance in autotrophic production (Abd El-aal, 2008). Pond culture is commonly practiced in ponds of about $1 \mathrm{~m}$ depth, but there is a wide range of depths in use. Depth may be chosen for reasons relating to construction costs, habitat preference of the primary cultured species, or management of cohabiting organisms such as phytoplankton, benthos or rooted macrophytes (Carballo et al., 2008). The present study aimed to investigate the effect of pond water depth on growth performance and survival rate during over wintering period in two body sizes of Nile tilapia under the Egyptian conditions.

\section{MATERIALS AND METHODS}

This study was conducted in standing cages placed in cement ponds in cold season from January $10^{\text {th }}$ to April $10^{\text {th }}$., 2011 located at the Fish Research Center, Suez Canal University, Ismailia, Egypt.

\section{Experimental fish}

Nile tilapia (Oreochromis niloticus) with two different sizes ( fingerlings of an average weight 18 gm and average total length of $9.75 \mathrm{~cm}$, and adults of an average weight $100 \mathrm{gm}$ and the aversge total length $17.65 \mathrm{~cm}$ ) were obtained from Fish Research Center, Suez Canal University. Every size of fish were homogenous in size, body weights and apparently healthy.

\section{Experimental cages}

Twelve standing cages $(100 \times 200 \times 200 \mathrm{~cm})$ were used. The standing cages had a supporting frame of steel extending $0.3 \mathrm{~m}$ below the cage floor to keep it away from the bottom sediment. The mesh walls are attached to the upper part of this frame, a polyethylene net with a mesh size of $10 \mathrm{~mm}$ was fixed inside cages and cleaned by washing every two weeks in order to prevent the growth of algae on it, the cages were placed in a cement pond (measuring $20 \times 10 \mathrm{~m}$ and an average depth of $2 \mathrm{~m}$ ) having fresh water pumped from Ismailia fresh water canal (salinity of $0.4 \mathrm{ppt}$ and total alkalinity of $112.2 \mathrm{mg} / \mathrm{l}$ $\mathrm{CaCO}_{3}$ ).

\section{Experimental design}

Fish were reared in 3 different water depths 75, 125 and $175 \mathrm{~cm}$ respectively,. Tilapia was stocked at 
a rate of thirty fish $/ \mathrm{m}^{3}$ of water from each size ( 18 and $100 \mathrm{gm}$ ) for 90 days, each size was replicated twice in each treatment. Fishes were fed on commercial diet $(26.58 \%$ protein) for the next period from (Feb. $24^{\text {th }}$ ) to the end of the experiment and was not fed during the first 45 days of the experiment $\left(\right.$ Jan. $10^{\text {th }}$ to Feb. 23 ${ }^{\text {th }}$. The dissolved oxygen, temperature, $\mathrm{pH}$, UIA-N and transparency of water and mortality were recorded biweekly for each cage. Also, at the end of the experimental period, the fish were harvested, counted and the growth measurements were recorded.

\section{Experimental diet}

The diet used from El Bardeny Company, pellets size $2 \mathrm{~mm}$ was contained $26.58 \%$ crude protein according to (Stickney, 1997). The diet was stored in a refrigerator $\left(4^{\circ} \mathrm{C}\right)$ during the experimental duration to avoid the nutrients deterioration. Contents and proximate chemical analysis of the experimental diet are provided in Table (1).

Table 1. Ingredients composition and proximate analysis of the diet fed to Tilapia fish

\begin{tabular}{ll}
\hline Ingredients & $\%$ \\
\hline Fish meal & 19.76 \\
Soya bean meal & 19.76 \\
Yellow corn & 25.69 \\
Wheat bran & 25.69 \\
Fish oil & 3.95 \\
Mineral mix* & 2.68 \\
Vitamin mix** & 2.47 \\
Total & 100 \\
\hline
\end{tabular}

Proximate chemical analysis (\% DMB)

\begin{tabular}{ll}
\hline Ash & 15.03 \\
Crude protein & 26.58 \\
Crude fat & 13.75 \\
Crude fiber & 4.00 \\
Nitrogen-free extract & 40.64 \\
\hline
\end{tabular}

*Mineral mix (El Bardeny Company),each $0.25 \mathrm{~kg}$ contains: Iron 30,000 mg ; Manganese 60,000 mg ; Zinc $50,000 \mathrm{mg}$; Copper 4,000 mg ; Cobalt $100 \mathrm{mg}$; Iodine $300 \mathrm{mg}$ and Selenium $100 \mathrm{mg}$.

** Vitamin mix. ,each $0.25 \mathrm{~kg}$ contains: (A) $10,000,000$ IU ; (D3) 2,200,000 IU; (E) 10,000 mg; (K3) 1,000 mg; (B1) 1,000 mg ; (B2) 5,000 mg ; (B6)1,500 mg ; (B12) $10,000 \mathrm{mg}$; Panthotenic acid 10,000 mg ; Niacin 30,000 $\mathrm{mg}$; Folic acid 1,000 mg ; Biotin 50,000 mg ; Colinechloride 600,000 mg.

\section{Feeding regime}

Fish was unfed during the first 45 days of the experiment (Jan.10 ${ }^{\text {th }}$ to Feb. 23 $3^{\text {th }}$ ) because of the lower water temperature and consequently the fish ceased on feeding (Abd El-aal, 2008). While, the daily feeding rate was $3 \%$ of the fish biomass for the next period from (Feb. 24 ${ }^{\text {th }}$ ) to the end of the experimental period. The fish were weighed every two weeks and the amount of food was adjusted for the next growth period based on the new fish biomass in each cage .The daily feeding rate (percent of the body weight) were assigned to a particular range of wet weight according to (NRC, 1993). The experimental diet was offered by hand spreading over cages.

\section{Water Sampling}

The water sampling bottle was filled from the bottom of each depth and then overflows until the space surrounding the bottle is filled. By using this apparatus the water in the sample bottle dose not contact air and the bottle is filled directly (Diana and Lin, 1998).

\section{Physico-chemical analysis of water}

Water $\mathrm{pH}$ was measured daily in the late afternoon using $\mathrm{pH}$ meter model 56, NR 87 BB 203 ( $\operatorname{Rad}$ et al., 2006), the average was recorded biweekly throughout the experimental period.

Transparency was measured twise weekly by using Secchi-disk visibility $(20 \mathrm{~cm}$ diameter secchi disk). It was calculated as the average between depth at which the reading of secchi disk disappeared when lowered and the depth at which reappeared when raised (Boyd and Tucker, 1992). Water temperature was measured daily using oxygen-temperature meter (YSI model L57) and the average was taken biweekly. The dissolved oxygen of the water was measured daily in the early morning by using oxygen-temperature meter (YSI model L57) and the average was recorded biweekly (Pullin and McConell, 1982). The total ammonia concentration in the water was measured biweekly in each depth by using ammonia ion specific meter (HI93715) which measures the ammonia nitrogen (NH4-N) content in the water and the average was recorded every 15 days during the experimental period, un-ionized ammonia (toxic to fish) it was calculated from total ammonia using temperature $-\mathrm{pH}$ tables (Emerson $e t$ al., 1975).

\section{Growth parameters}

The following parameters were used to evaluate tilapia growth performance

Body weight gain $(\mathrm{WG})=\mathrm{W} 1-\mathrm{W} 0$, Average daily body weight gain (ADG): $\mathrm{ADG}=(\mathrm{W} 1-$ $\mathrm{W} 0) / \mathrm{t})$, Specific growth rate $(\% /$ day $)$ : SGR=(Ln W1Ln W0 $\times 100 /$ t), Food conversion ratio: $\mathrm{FCR}=\mathrm{Df} /(\mathrm{W} 1-\mathrm{W} 0), \quad$ Survival rate $(\%): \mathrm{SR}=\mathrm{Ni} \times 100 / \mathrm{N} 0$, where:W1=Final wet weight, $\mathrm{Wo}=$ Initial wet weight, $\mathrm{t}=$ Time interval in days, $\mathrm{Ni}=$ Number of fishes at the end, $\mathrm{N} 0=$ Number of fishes initial stocked and Df=Dry feed intake.

\section{Statistical analysis}

The data obtained were analyzed by one-way ANOVA Procedure of Statistical Analysis System (SAS, 1988). Means were compared by Duncan's new multiple range test (Zar, 1996). 


\section{RESULTS AND DISCUSSION}

The physico-chemical characteristics of water

Mean water temperature, dissolved oxygen, $\mathrm{pH}, \mathrm{NH} 3-\mathrm{N}$ and secchi disk depth at different depths $(75,125$ and $175 \mathrm{~cm})$ which were measured and recorded every 15 days intervals are indicated in Table 2. The average water temperature during the experimental period fluctuated between (12.90 and $\left.14.70^{\circ} \mathrm{C}\right)$ in Jan. $25^{\text {th }}-$ Feb. $8^{\text {th }}$ and $\left(20.91\right.$ and $22.50^{\circ}$ C) in Mar. $26^{\text {th }}-$ Apr. $9^{\text {th }}$ for depths 75,125 and 175 $\mathrm{cm}$ respectively, thus, it seems that the temperature of the water through the rearing period is generaly unsuitable for the growth of tilapia and varied according to the water depth since it increase by increasing water depth as reported by (Stoll et al., 2008 and Abd El-aal, 2008) who found that ponds tend to become colder in the winter and warmer in the summer it could be due to the high heat capacity of water which changes water temperature relatively slowly and fairly evenly. Values of $\mathrm{pH}$ ranged from $7.90-8,8.0-8.30$ and $8.30-8.50$ for depths 75 , 125 and $175 \mathrm{~cm}$, respectively which were in the range at which tilapia live as recorded by El-Sherif and El-Feky (2009b); Ju n et al. (2012) and Duy et al. (2012) who reported that $\mathrm{pH}$ values of $7-8.3$ are quite common and most suitable for fish, the slight increases opserved in $\mathrm{pH}$ values at deeper depth could be attributed to the content of organic matter on the pond bottom. Dissolved oxygen concentrations were decreased with increased water depth but it is clear that the dissolved oxygen at different depths is suitable for tilapia feeding and growth as reported by Rad et al. (2006) the lowest concentrations of dissolved oxygen might be attributed to: Firstly: excess concentration of phytoplankton algae, though algae are DO producers, they also reduce light penetration and consume DO in the dark, excess algae therefore reduce DO production in the lower layers of the water and increase the rate of depletion of DO during the night, Secondly: abundance of organic matter on the pond bottom which increases bacterial population rapidly and consumes oxygen (Khouraiba, 1989). The UIA$\mathrm{N}$ was suitable for growth of Nile tilapia and gradually increased with increasing depth and $\mathrm{pH}$, this was in agreement with (El-Sherif and El-Feky, 2009 a,b) who showed that Nile tilapia produced the best growth rate when UIA-N ranging from 0.01 to $0.08 \mathrm{mg} / \mathrm{l}$. The average secchi disk visibility throughout the experimental period was $45-47 \mathrm{~cm}$ which was suitable for growth of Nile tilapia, this result was attributed to the concentration of phytoplankton algae (Diana and Lin, 1998). However, the visibility reading were similar among all treatments, indicating that feed served not only as fish feed but also as a sourse of nutrients of aquatic populations such as phytoplankton, that contribute to productivity. Generaly, Secchi disk has been found to provide a rough estimate of phytoplankton abundance in culture ponds (Boyd, 1979).

Table 2. The physico-chemical characteristics of the water of the experimental ponds in the Fish Research Center, Suez Canal University (from 10 January to 9 April., 2011)

\begin{tabular}{|c|c|c|c|c|c|c|c|}
\hline \multirow[b]{2}{*}{ Parameter } & \multirow{2}{*}{$\begin{array}{c}\text { Depth } \\
\text { (cm) }\end{array}$} & \multicolumn{6}{|c|}{ Period of rearing } \\
\hline & & $\begin{array}{c}\text { Jan 10- } \\
24^{\text {th }}\end{array}$ & $\begin{array}{c}{\text { Jan } 25^{\text {th }}} \\
\text { Feb } 8^{\text {th }}\end{array}$ & Feb $9-23^{\text {th }}$ & $\begin{array}{l}\text { Feb 24}{ }^{\text {th }}- \\
\text { Mar10 }\end{array}$ & $\underset{25^{\text {th }}}{\operatorname{Mar} 11-}$ & $\begin{array}{c}\text { Mar } 26^{\text {th }}- \\
\text { Apr } 9^{\text {th }}\end{array}$ \\
\hline \multirow{3}{*}{$\begin{array}{l}\text { Temperature } \\
\left({ }^{\circ} \mathrm{C}\right)\end{array}$} & 75 & 13.60 & 12.90 & 13.80 & 16.00 & 18.75 & 20.91 \\
\hline & 125 & 14.00 & 13.70 & 14.25 & 16.70 & 19.00 & 21.50 \\
\hline & 175 & 15.60 & 14.70 & 15.30 & 17.80 & 19.88 & 22.50 \\
\hline \multirow{3}{*}{ pH } & 75 & 7.90 & 8.00 & 7.92 & 7.80 & 7.90 & 7.90 \\
\hline & 125 & 8.00 & 8.20 & 8.10 & 8.22 & 8.10 & 8.30 \\
\hline & 175 & 8.50 & 8.40 & 8.30 & 8.34 & 8.33 & 8.50 \\
\hline \multirow{3}{*}{$\begin{array}{l}\text { Do } \\
(\mathrm{mg} / \mathrm{L})\end{array}$} & 75 & 7.60 & 8.00 & 7.80 & 8.10 & 8.00 & 7.80 \\
\hline & 125 & 7.00 & 7.60 & 7.30 & 7.80 & 7.60 & 7.50 \\
\hline & 175 & 6.40 & 6.60 & 6.40 & 7.00 & 6.80 & 6.80 \\
\hline \multirow{3}{*}{$\begin{array}{l}\mathrm{NH}_{3} \\
(\mathrm{mg} / \mathrm{L})\end{array}$} & 75 & 0.01 & 0.02 & 0.01 & 0.02 & 0.01 & 0.01 \\
\hline & 125 & 0.03 & 0.03 & 0.02 & 0.03 & 0.02 & 0.03 \\
\hline & 175 & 0.05 & 0.05 & 0.06 & 0.05 & 0.04 & 0.05 \\
\hline $\begin{array}{l}\text { Secchi disk } \\
\text { (depth) }\end{array}$ & $\begin{array}{c}\text { At } \\
\text { all } \\
\text { depth }\end{array}$ & 45 & 47 & 45 & 47 & 46 & 45 \\
\hline
\end{tabular}

*Un - ionized ammonia (toxic to fish) it was calculated from total ammonia $\left(\mathrm{NH}^{+}{ }_{4}+\mathrm{NH}_{3}\right)$ using temperature $-\mathrm{pH}$ equilibrium tables (Emerson et.al., 1975). 
The growth and survival rate of Nile tilapia (fingerlings and adult)

From the presented data in Tables (3) and (4), it is obvious that the growth parameters increase (body weight and body length) as the water depth increases in both two sizes of tilapia, since, the depth of 175 $\mathrm{cm}$ showed highest increases. These results are in full agreement with those obtained by Dan and Little (2000); Takashi and Tadashi (2003) and Stoll et al.(2008). Also, it is clear that the poorest condition factor and specific growth rate was that of fish reared in the lower water depth, while fish reared in deeper water showed the best condition factor and SGR in both two sizes of tilapia, these results agree well with the data obtained by El-Sayed et al. (1996) and Abd El-aal (2008). Results of Table (3) revealed that the specific growth rates for fingerlings were higher than of the adult ones at different water depths used, this may be attributed to the size of fish reared under the same experimental and ecological conditions. The statistical analyses indicated that there were significant differences $(\mathrm{P} \leq 0.05)$ in growth parameters between all depths. The high survival rate $\%$ in water depth $(175 \mathrm{~cm})$ for both two sizes of tilapia was attributed to that the fishes live naturally in deeper water during the cold season and migrate to shallower water when the water warms up so fish avoided low water temperature during winter by moving to the bottom, and this reduced mortality. The poor survival rate in both two sizes of tilapia with shallow water of $75 \mathrm{~cm}$ might be attributed to the poor of ecological conditions of the fish especially low water temperature at this depth, growth rates were extremely reduced, fungal infection occur due to the decrease in feeding activity and metabolic scope where a substantial amount of dietary energy was used to maintain the internal physiological functions rather than for growth during the winter season, also, survival rate for fingerlings was higher than that of the adult fish at different water depths, this may be due to the size of fish cultured under the same experimental and environmental conditions, also, small fish are more capable than adults of rapid adaptation to variation in water temperature and depth. This conclusion is in agreement with finding of Khouraiba (1989); ElSayed et al. (1996); Charo-Karisa et al. (2005) and Abd El-aal (2008). They cited that the young tilapia generally being more tolerant to lower temperature than the large tilapia, the statistical analyses indicated that there were significant differences $(\mathrm{P} \leq 0.05)$ in survival \% between all depths. Based on the obtained results it could be concluded that $175 \mathrm{~cm}$ water depth was more suitable for the growth and survival \% of Nile tilapia fingerlings cultured during the cold season in Egypt.

\section{ACKNOWLEDGEMENT}

This study is a part of Ph.D. Thesis of Amal Mohamed Ibrahim Elfeky submitted to Suez Canal University.

Table 3. The growth and percentage of survival of Nile tilapia fingerlings (average weight $18 \mathrm{~g} /$ fish) reared in standing cages for a period of 90 days at different water depths.

\begin{tabular}{|c|c|c|c|c|}
\hline \multicolumn{2}{|r|}{ Item } & \multicolumn{3}{|c|}{ Water depth(cm) } \\
\hline & & 75 & 125 & 175 \\
\hline \multirow{4}{*}{ 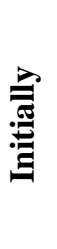 } & No. of fish(30 fish/: $\left.\mathbf{m}^{3}\right)$ & 45 & 75 & 105 \\
\hline & Av. Individual weight of fish (gm/fish) & 18.00 & 18.00 & 18.00 \\
\hline & Av. Individual total length of fish (cm/fish) & 9.75 & 9.75 & 9.75 \\
\hline & Condition factor (CF) & 1.94 & 1.94 & 1.94 \\
\hline \multirow{8}{*}{ 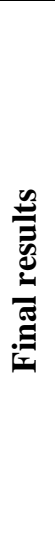 } & No. of fish(fish $\left./ \mathrm{m}^{3}\right)$ & 30 & 56 & 89 \\
\hline & Av. Individual weight of fish (gm/fish) & $20.16 \pm 0.05^{c}$ & $26.11 \pm 0.02^{b}$ & $30.66 \pm 0.04^{\mathrm{a}}$ \\
\hline & Body weight gain (gm/fish) & $2.16 \pm 0.02^{c}$ & $8.11 \pm 0.05^{b}$ & $12.66 \pm 0.01^{\mathrm{a}}$ \\
\hline & Av. Individual total length of fish (cm/fish) & $10.55 \pm 0.05^{\mathrm{c}}$ & $11.40 \pm 0.03^{\mathrm{b}}$ & $11.80 \pm 0.05^{\mathrm{a}}$ \\
\hline & Body length gain (cm/fish) & $0.8 \pm 0.05^{c}$ & $1.65 \pm 0.02^{b}$ & $2.05 \pm 0.01^{\mathrm{a}}$ \\
\hline & Specific growth rate (\% growth/d) & $0.13 \pm 0.01^{c}$ & $0.41 \pm 0.05^{b}$ & $0.59 \pm 0.02^{a}$ \\
\hline & Survival rate $(\%)$ & $66.67 \pm 0.02^{c}$ & $74.67 \pm 0.05^{b}$ & $84.76 \pm 0.03^{a}$ \\
\hline & Condition factor (CF) & $1.72 \pm 0.01^{\mathrm{c}}$ & $1.76 \pm 0.05^{b}$ & $1.86 \pm 0.04^{\mathrm{a}}$ \\
\hline
\end{tabular}


Table 4. The growth and percentage of survival of adult Nile tilapia (average weight $100 \mathrm{~g} /$ fish)

\begin{tabular}{|c|c|c|c|c|}
\hline & \multirow{2}{*}{ Item } & \multicolumn{3}{|c|}{ Water depth $(\mathrm{cm})$} \\
\hline & & 75 & 125 & 175 \\
\hline \multirow{4}{*}{$\stackrel{\text { 恶 }}{\stackrel{\Xi}{\Xi}}$} & No. of fish $\left(30 \mathrm{fish} / \mathrm{m}^{3}\right)$ & 45 & 75 & 105 \\
\hline & Av. Individual weight of fish (gm/fish) & 100.00 & 100.00 & 100.00 \\
\hline & Av. Individual total length of fish ( $\mathrm{cm} /$ fish) & 17.65 & 17.65 & 17.65 \\
\hline & Condition factor $(\mathrm{CF})$ & 1.82 & 1.82 & 1.82 \\
\hline \multirow{8}{*}{ 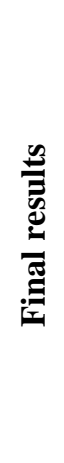 } & No. of fish(fish $\left./ \mathrm{m}^{3}\right)$ & 15 & 48 & 63 \\
\hline & Av. Individual weight of fish (gm/fish) & $107.11 \pm 0.05^{\mathrm{c}}$ & $113.1 \pm 0.02^{\mathrm{b}}$ & $120.13 \pm 0.05^{\mathrm{a}}$ \\
\hline & Body weight gain (gm/fish) & $7.11 \pm 0.04^{\mathrm{c}}$ & $13.12 \pm 0.05^{\mathrm{b}}$ & $20.13 \pm 0.01^{\mathrm{a}}$ \\
\hline & Av. Individual total length of fish (cm/fish) & $18.81 \pm 0.05^{\mathrm{c}}$ & $18.84 \pm 0.02^{\mathrm{b}}$ & $19.15 \pm 0.03^{\mathrm{a}}$ \\
\hline & Body length gain (cm/fish) & $1.16 \pm 0.02^{c}$ & $1.19 \pm 0.03^{\mathrm{b}}$ & $1.5 \pm 0.01^{\mathrm{a}}$ \\
\hline & Specific growth rate (\%growth/d) & $0.08 \pm 0.01^{\mathrm{c}}$ & $0.14 \pm 0.03^{\mathrm{b}}$ & $0.20 \pm 0.05^{\mathrm{a}}$ \\
\hline & Survival rate $(\%)$ & $33.3 \pm 0.02^{c}$ & $48.0 \pm 0.05^{\mathrm{b}}$ & $60.0 \pm 0.03^{\mathrm{a}}$ \\
\hline & Condition factor $(\mathbf{C F})$ & $1.61 \pm 0.05^{\mathrm{c}}$ & $1.69 \pm 0.01^{\mathrm{a}}$ & $1.71 \pm 0.05^{\mathrm{b}}$ \\
\hline
\end{tabular}

\section{REFERENCES}

Abd El-aal, M.M., 2008. Effects of over-wintering and water depth on growth performance of Nile tilapia, (Oreochromis niloticus) 8th International Symposium on Tilapia in Aquaculture pp.297305.

Biswas, A. K., M. Seoka, Y. Inoue, K. Takii and H. Kumai, 2005a. Photoperiod influences the growth, food intake, feed efficiency and digestibility of red sea bream Pagrus major. Aquaculture, 250: 666-673.

Boyd, C. E., 1979. Water quality in warm water fish ponds. (Book) Auburn Univ. Agricultural Experiment Station, Auburn, Alabama.

Boyd, C.E. and C.S. Tucker, 1992. Water quality and pond soil analyses for aquaculture. Auburn University, Alabama.

Carballo, E., A. Eer, T. Schie and A. Hilbrands, 2008. Small-scale freshwater fish farming. Agromisa Foundation and CTA, Wageningen, book, 1:83.

Charo-Karisa, H., M. A. Rezk, H. Bovenhuis and H. Komen, 2005. Heritability of cold tolerance in Nile tilapia, Oreochromis niloticus, juveniles. Aquaculture, 249: 115123.

Dan, N.C. and D.C. Little, 2000.Overwintering performance of Nile tilapia, Oreochromis niloticus (L.) broodfish and seed at ambient temperatures in northern vietnam. Aquaculture Research, 31,485-493.

De-Silva, S.S. and T.V. Anderson, 1995. Fish Nutrition in Aquaculture (Book) .Printed in Great Britain by St. Edmundsbuzy Press, Bury St.Dmunds, Subfolk.

Diana, J.S. and C.K. Lin, 1998. The Effects of Fertilization and Water Management on
Growth and Production of Nile Tilapia in Deep Ponds during the Dry Season. Journal of the world aquaculture society, 29(4).

Duy, A.T., A. A. Dam and J.W. Schrama, 2012. Feed intake, growth and metabolism Nile tilapia (Oreochromis niloticus) in relation to dissolved oxygen Concentration. Aquaculture Research, 43: 730-744.

El-Sayed, A.F.M., A. EI-Ghobashy and M. AlAmoudi, 1996. Effects of pond depth and water temperature on the growth, mortality and body composition of Nile tilapia, Oreochromis niloticus (L.). Aquaculture Research, 27:681-687.

El-Sayed, A. M. and M. Kawanna, 2004. Effects of photoperiod on the performance of farmed Nile tilapia Oreochromis niloticus: I. growth, feed utilization efficiency and survival of fry and fingerlings. Aquaculture, 231:393-402.

El-Sherif, M.S. and A.M.I. El-Feky, 2009a. Performance of Nile tilapia Oreochromis niloticus fingerlings. II. Influence of different water temperatures. International Journal of Agriculture and Biology, 11:301-305.

El-Sherif, M.S. and A.M.I. El-Feky, $2009 \mathrm{~b}$. Performance of Nile Tilapia Oreochromis niloticus fingerlings. I. Effect of $\mathrm{pH}$. International Journal of Agriculture and Biology, 11: 297-300.

Emerson, K., R.C. Russo, R.E. Lund, and R.V. Thurston, 1975. Aqueous ammonia equilibrium calculations: Effect of $\mathrm{pH}$ and temperature. journal of the fisheries research, 32: 2379- 2383.

Jun, Q., X. Pao, W. Haizhen, L. Ruiwei and W. Hui, 2012. Combined effect of temperature, salinity and density on the growth and feed utilization of Nile tilapia juveniles (Oreochromis niloticus). Aquaculture Research, 43: 1344-1356.

Neill, W.H. and J.D. Bryan, 1991. Responses of fish to temperature and oxygen, and responses 
integration through metabolic scope. In: Aquaculture and Water Quality (ed. By D.E. Brune \& J.R. Tomasso), pp. 30-57. The World Aquaculture Society, Baton Rouge, LA, USA.

NRC (National research council) 1993. Nutrient requirements of fish. National Academy Press Washington, D.C.

Pullin, R.S.V. and L.R.H. McConell, 1982. The Biology and Culture of Tilapias. Proceedings of the International Conference on the Biology and culture of Tilapias, 2-5 September 1980 Manile, Philippines.

Rad, F., S. Bozaoğlu, S. E. Gözükara, A. Karahan and G. Kurt, 2006. Effects of different long- day photoperiods on somatic growth and gonadal development in Nile tilapia Oreochromis niloticus L. Aquaculture 255: 292-300.

SAS, 1988. SAS user's guide. Statistics. A. A. Ray.ed. SAS Inst., Inc., Cary, Nc., 67 .

Sifa, L., L. Chenhong, M. Dey, F. Gagalac, and R. Dunham, 2002. Cold tolerance of three strains of
Nile tilapia, Oreochromis niloticus, in China. Aquaculture, 213:123-129.

Stoll, S., P. Fischer, P. Klahold, N. Schelfhacken, H. Hofmann and K.O. Rothhaupt, 2008. Effects of water depth and hydrodynamics on the growth and distribution of juvenile cyprinids in the littoral zone of a large pre-alpine lake. Journal of Fish Biology, 72:1001-1022.

Stickney, R.R., 1997. Tilapia nutrition, Feeds and Feeding. In: Tilapia Culture in the Americas, Eds. B.A. Costa-Pierce and J.E. Rakocy. vol.1 World Aquaculture Society, Baton Rouge, Louisiana.

Takashi, K. and K. Tadashi, 2003. Water Depth as a Factor Influencing Growth Rate and Size of the Japanese Endemic Crayfish Cambaroides japonicus (Crustacea: Decapoda).Japanese Journal of Benthology, 58:11-15.

Zar, J.H., 1996. Biostatistical Analysis. Prentice Hall, Upper Saddle River, Nj, USA.

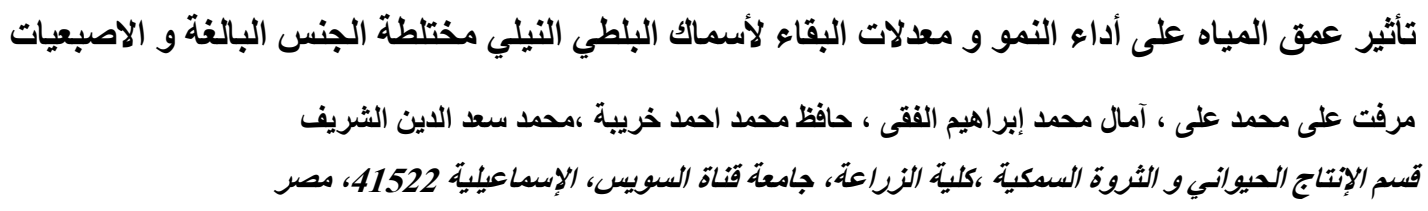

تم تربية اسماك البلطي النيلي ( اصبعيات و اسماك بالغة بمتوسط وزن 19 و 100 جر ام على التو التو الي) تحت ثلاثة أعماق مختلفة للمياه ( 25،

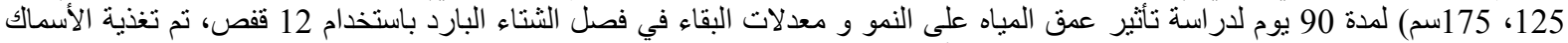

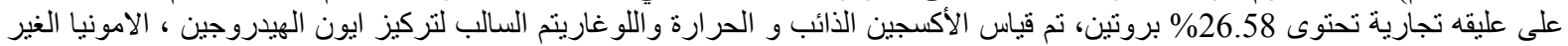

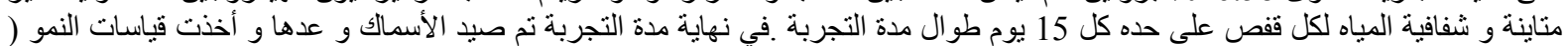

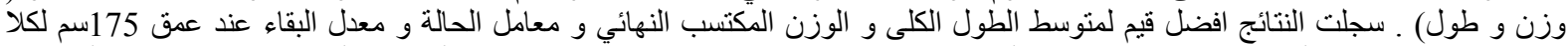

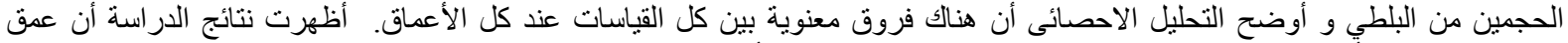

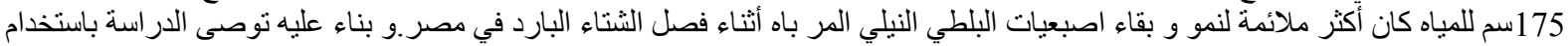

